\title{
"CHANNELING THOUGHT": THE LEGACY OF LEGAL FICTIONS FROM 1823
}

\author{
Jen Camden"* \& Kathryn E. Fort ${ }^{* * *}$
}

\section{Introduction}

When ... the conquered inhabitants can be ... safely governed as a distinct people, public opinion, which not even the conqueror can disregard, imposes these restraints upon him; and he cannot neglect them without injury to his fame, and hazard to his power. ${ }^{1}$

When Cooper was finished, New Yorkers-and all the world, for that matter-could see the state, in all its versatile expanse, as it had never been seen before. ${ }^{2}$

James Fenimore Cooper's novel The Pioneers ${ }^{3}$ and Chief Justice John Marshall's opinion Johnson v. M'Intosh ${ }^{4}$ were published in the same year, 1823. Both take part in the contemporary debate over indigenous land rights from a similar authorial viewpoint - that of white male landowners. Marshall's opinion, however, has the force of law behind it, while Cooper's novel is merely a work of popular literature. That said, Johnson was certainly read by far fewer people than The Pioneers. ${ }^{5}$ While Marshall's opinion became

(C) 2009 Jen Camden \& Kathryn E. Fort

* Aviam Soifer, Reviewing Legal Fictions, 20 GA. L. REV. 871, 877 (1986) ("[I]f accepted, a legal fiction channels thought.").

** Assistant Professor of English, University of Indianapolis. I would like to thank my wonderful colleagues and my family, especially Eric Landen, for their support, advice, and encouragement.

*** Adjunct Professor, Michigan State University College of Law; Staff Attomey, Indigenous Law and Policy Center. This paper was prepared for the 4th Annual Indigenous Law Conference, "American Indian Law and Literature," at Michigan State University College of Law (October 19-20, 2007). Thank you to Matthew L.M. Fletcher, Wenona T. Singel, Ross and David Fort, and Diane and Ken Henningfeld.

1. Johnson v. M'Intosh, 21 U.S. (8 Wheat.) 543, 589-90 (1823).

2. Thomas F. O'Donnell, Literary History of New York, 1650-1958, in UPSTATE LITERATURE: ESSAYS IN MEMORY OF THOMASF. O'DONNELL 3, 7 (Frank Bergmann ed., 1985).

3. James Fenimore CoOPER, The PIONEers (Donald Ringe ed., Penguin 1988) (1823).

4. Johnson, 21 U.S. (8 Wheat.) 543.

5. COOPER, supra note 3, at vii ("Published in 1823 , the book was an immediate success and established him in a career as a professional novelist."). 
the foundation for decisions regarding tribal land rights, Cooper's novel served as the equal cultural touchpoint for the reasoning behind Johnson. Cooper's work, understood as both fiction and memoir, ${ }^{6}$ gives life to the same legal fictions used by Justice Marshall to dispossess all tribes of title to their land.

In bringing together The Pioneers and Johnson, this article participates in a larger tradition of the study of law and literature. From James Boyd White ${ }^{7}$ to Robert Cover $^{8}$ and Robin West, ${ }^{9}$ scholars have been interested in the relationship between these fields, both of which rely on storytelling and locate power in the written word. Early scholarship focused on critical reading of text by applying literary theory to the law. ${ }^{10}$ Scholars used the tools of literary criticism to understand the law, and particularly legal opinions, as a narrative. ${ }^{11}$ In doing so, critics were able to talk about whose stories were being told by judges and whose were not. The combination of critical race theory and the study of law and literature provided scholars a way of demonstrating that though one view of a story or history had the force of law, this dominant narrative was created, at least in part, through the suppression of alternative minority narratives. ${ }^{12}$

6. See, e.g., Alan TAylor, William CoOPER's Town: Power and Persuasion On the FRONTIER OF THE EARLY AMERICAN REPUBLIC 53 (1995) ("One of the newcomers who preceded Cooper's visit was a squatter named David Shipman, who later served as a model for the hunter Natty Bumppo in The Pioneers.").

7. JAMES BOYD WHTTE, ACTS OF HOPE: CREATING AUTHORITY IN LITERATURE, LAW AND Politics (1994); JAMEs Boyd WhITE, HeRACles' Bow: EsSAYS ON THE RHETORIC AND PoETICS OF THE LAw (1985); James Boyd White, Law as Language: Reading Law and Reading Literature, 60 TEX. L. REV. 415 (1982) [hereinafter White, Law as Language]. For a discussion of White's work, see Robert Weisberg, The Law-Literature Enterprise, 1 YALE J. L. \& HUMAN. 1, 54-59 (1989) and Robin West, The Literary Lawyer, 27 PAC. L.J. 1187 (1996) [hereinafter West, Literary Lawyer].

8. Robert M. Cover, Nomos and Narrative, 97 HARV. L. REV. 4 (1983).

9. ROBIN WEST, NARRATIVE, AUTHORITY, AND LAW (1993); West, Literary Lawyer, supra note 7; Robin West, Adjudication Is Not Interpretation: Some Reservations About the Law-asLiterature Movement, 54 TENN. L. REV. 203 (1986) [hereinafter West, Adjudication Is Not Interpretation].

10. See, e.g., White, Law as Language, supra note 7.

11. Bruce Duthu, Incorporative Discourse in Federal Indian Law: Negotiating Tribal Sovereignty Through the Lens of Native American Literature, 13 HARV. HUM. RTS. J. 141, 148 (2000).

12. Milner S. Ball, Stories of Origin and Constitutional Possibilities, 87 MiCH. L. REv. 2280,2296 (1989) ("No version of the American story gives full voice to Native Americans. The American legal order debars the autonomy of tribes and the possibility of dialogue with them as independent centers of sovereignty."); Richard Delgado \& Jean Stefancic, Norms and Narratives: Can Judges Avoid Serious Moral Error?, 69 TEX. L. REV. 1929 (1991). 
The tensions between fiction and history or between minority and majority narratives are particularly compelling in the study of legal fictions. ${ }^{13}$ Legal fictions, or statements understood by lawyers and judges to be false, ${ }^{14}$ but that lead to a consistent holding in the law, are rarely questioned as anything other than a tool the law uses to ensure a fair or consistent conclusion. ${ }^{15}$ Although the parties to a given case may accept a legal fiction for the sake of reaching a consistent conclusion, the use of legal fictions to set precedent raises an interesting question: Do legal fictions remain fictions over time, or do they acquire the patina of fact? Specifically, are legal fictions written in 1823, such as those used in Johnson, still considered fictions, or have they become historical fact? Moreover, while legal fictions are expected in the law, they also exist in literature-as fiction, of course. What happens, however, when a work of literature is also a thinly veiled memoir? Does the reading audience understand the text as fiction or history? In other words, both legal fictions and fiction can take on the authority of history.

This article looks at two works as examples of legal fictions that are both self- and mutually reinforcing. ${ }^{16}$ The first, Johnson, creates the legal fiction of discovery and conquest to ensure a smooth chain of title-and permanently dispossess tribes of full title to their land in Anglo-American courts. ${ }^{17}$ The second, The Pioneers, popularized the fictions of the "vanishing Indian" and open wilderness to the west, ${ }^{18}$ reinforcing Justice Marshall's similar language. ${ }^{19}$ The Pioneers is an apt literary comparison, not only because the

13. Whether the study of legal fictions belongs in the study of law and literature may be questioned, but as Professor Soifer points out, "[T] hey pose special challenges for the best work on law and literature." Soifer, supra note *, at 873.

14. LON L. FULLER, LEGAL FICTIONS 7 (1967).

15. Of course, these are not always the same thing.

16. From the perspective of law and literature, only two articles have compared these two pieces: Susan Scheckel, "In the Land of His Fathers": Cooper, Land Rights, and the Legitimation of American National Identity, in JAMES FENIMORE COOPER: NEW HISTORICAL AND LITERARY CONTEXTS 125 (W.M. Verhoeven ed., 1993) and Eric Cheyfitz, Savage Law: The Plot Against American Indians in Johnson and Graham's Lessee v. M'Intosh and The Pioneers, in Cultures of UnITEd States IMPERIALISM 109 (Amy Kaplan \& Donald E. Pease eds., 1993).

17. Johnson v. M'Intosh, 21 U.S. (8 Wheat.) 543, 588 (1823) ("All our institutions recognize the absolute title of the crown, subject only to the Indian right of occupancy, and recognize the absolute title of the crown to extinguish that right. This is incompatible with an absolute and complete title in the Indians.").

18. West, at least, of where most of Cooper's readers were. See, e.g., HENRY NASH SMTTH, VIRGIN LAND: THE AMERICAN WEST AS SYMBOL AND MYTH (1950).

19. Johnson, 21 U.S. (8 Wheat.) at 590-91 ("The game fled into thicker and more unbroken 
case and the book were released in the same year, but also because of the general perception of The Pioneers as a fictional work grounded in history: most readers understood the novel as a fictionalization of James Fenimore Cooper's childhood in upstate New York. The novel's fictional setting of Templeton and Cooper's portrait of Judge Marmaduke Temple are based on Cooper's father, Judge William Cooper, and hometown, Cooperstown. The Pioneers, then, was particularly positioned to do the "cultural work"20 needed to reinforce the legitimacy of Justice Marshall's decision. In this article, we build and expand on the work of Susan Scheckel and Eric Cheyfitz ${ }^{21}$ to argue that the legal fictions found in Marshall's opinion and Cooper's novel are mutually reinforcing and equally damaging to indigenous rights. Moreover, we suggest that Cooper's novel and Marshall's opinion each utilize narrative as a palliative in their attempt to gloss over past wrongs and create the legal fictions necessary to justify the tenancy of the American landscape by white settlers at the expense of Native land rights.

Part 1 of this article gives a brief history of the study of law and literature, with particular attention to the study of legal fictions as a key approach to federal Indian law. Parts 2 and 3 discuss Johnson v. M'Intosh, focusing primarily on its use of legal fictions and the continued relevance of this case today, both within and outside of federal Indian law. Part 4 extends our discussion of legal fictions to The Pioneers, James Fenimore Cooper, and his father, William Cooper. Finally, Part 5 argues that the mutually reinforcing themes in Johnson and The Pioneers remain dangerous to this day.

\section{Law, Literature, Legal Fictions, and Federal Indian Law}

The study of law and literature seems inevitable, though it is still a small area compared to other fields of jurisprudence. ${ }^{22}$ Both law and literature require that information is related in an order that is pleasing to their somewhat distinct audiences. Lawyers and judges prefer continuity with tradition; for example, judges tend to follow a specific format for a published opinion. ${ }^{23} \mathrm{~A}$

forests, and the Indians followed. The soil, to which the crown originally claimed title, being no longer occupied by its ancient inhabitants ....").

20. JANE TOMPKINS, SENSATIONAL DESIGNS: THE CULTURAL WORK OF AMERICANFICTION, 1790-1860, at xix (1985).

21. Scheckel, supra note 16; Cheyfitz, supra note 16.

22. But see, RICHARD POSNER, LAW AND LITERATURE: A MisUNDERSTOOD RELATION (1988).

23. Usually this consists of a summary or introduction of the case, which may reveal the final holding. Then, a statement of facts, procedural history, statement of applicable law, 
judge is free to choose what she wants to write within those structural restraints, as long as her opinion is consistent with the facts and law presented to her. However, as Indian law practitioners are well aware, the constraints provided by the facts in the case and legal precedent are not as rigid as one might believe. ${ }^{24}$ Still, few would make the argument that a judge is as free of constraints as a novelist when she sits down to write. ${ }^{25}$

However, novelists are also constrained by the historical precedents to their work. In other words, novelists are well aware of the history of the novel and of the basic structural elements of that genre that distinguish it from poetry, for example. Although early fictional works by Daniel Defoe and others employed an episodic structure, ${ }^{26}$ later works incorporated the familiar narrative arc common to novels today: readers expect, and typically discover, a clear beginning, rising action, conflict(s), climax, dénouement, and conclusion. Novels that reject or challenge this structure exist, of course, but one might argue that their self-conscious rejection of this pattern only proves its dominance. ${ }^{27}$

As William Charvat has argued, novels do not exist in isolation: each novel is subject to a network of relationships between author, publisher, and reader. ${ }^{28}$ To a greater or lesser extent, each novelist writes with an awareness of his or her audience and with an awareness of the publisher as a conduit to that audience. While authors can and often do reject the business side of publication, in the case of James Fenimore Cooper it is widely acknowledged he wrote The Pioneers in a last-ditch effort to make money and save the family land after the death of his father. ${ }^{29}$ Thus, in writing The Pioneers, Cooper

analysis and conclusion or holding. While not all opinions follow this format, most fall within some variant of it.

24. See, e.g., City of Sherrill v. Oneida Indian Nation, 544 U.S. 197 (2005) (basing the holding on legal defenses-laches, acquiescence, and impossibility-not briefed by either side).

25. Because the focus of this article is on a nineteenth century novel, the focus of the law and literature discussion will also be limited to novels, though certainly short stories and other fiction styles are not exempt from the study of law and literature. Interestingly, however, many law and literature articles are about novels. This may be due to their length and structure.

26. See, e.g., Daniel Defoe, Moll Flanders (G.A. Start ed., Oxford Univ. Press 1998) (1722).

27. See, e.g., Italo Calvino, If ON A WINTER's Night a Traveler (William Weaver trans., Minerva Press, 1979) (which self-consciously toys with the reader's desire for beginning, middle, and end through a series of "incipits"-sections of novels that abruptly end, usually at the "good part").

28. William Charvat, The Profession of Authorship IN AMERICA, 1800-1870 (Matthew J. Bruccoli ed., Columbia Univ. Press 1992).

29. THOMAS HALLOCK, FROM THE FALLEN TREE: FroNTIER NARRATIVES, ENVIRONMENTAL 
undoubtedly hoped to produce a commercially successful novel that, as Charvat and others have noted, conformed to the expectations of the audience and provided something new and entertaining for public consumption. ${ }^{30}$

Thus, both law and literature, in the form of legal opinions and novels, are constrained by audience expectations in equal and opposite directions: both rely on precedent and novelty. Legal opinions and novels draw on the formats and even content established by previous texts, but each promise to contribute something new. The conflict between precedent and novelty is echoed in the emphasis on argument essential to both genres. As Professor Dolin writes,

One of the movement's pioneers, James Boyd White has argued through a series of books that law is primarily a language, an interpretative and rhetorical enterprise like literature. Through the rhetorical analysis of literary, legal, historical and philosophic texts, he aims to demonstrate that the writing and reading inherent in the law in a democracy constitutes a 'culture of argument' a community open to the voice of the 'other' as well as its powerful. ${ }^{31}$

Thus, both law and literature provide a platform on which such conflicts can be staged: the opposing sides in a legal case find their counterpart in the protagonist and antagonist of a novel. In the end, however, the judge finds for either the plaintiff or the defendant; the novel, too, requires resolution.

As Robert Cover and Robin West have noted, the relative impact of these resolutions is very different. ${ }^{32}$ Cover and West claim that not only is law certainly not literature, it is also dangerous to consider it as such. ${ }^{33}$ Kieran Dolin explains:

In the midst of this interdisciplinary endeavour, one irreducible difference between law and literature has often been reasserted: that legal interpretation cannot be assimilated to literary interpretation, because the production and reception of texts within the law takes

POLITICS, AND THE ROOTS OF A NATIONAL PASTORAL, 1749-1826, at 200 (2003) ("During the period in which The Pioneers was written, a series of lawsuits devoured William Cooper's claims.").

30. CHARVAT, supra note 28.

31. KIERAN DOLIN, Fiction AND THE LAW: LEGAL DisCOURSE IN VictoriaN AND MODERNIST LITERATURE 8 (1999).

32. Robert M. Cover, Violence and the Word, 95 YALEL.J. 1601 (196); West, Adjudication Is Not Interpretation, supra note 9.

33. Cover, supra note 32, at 1601; West, Adjudication is Not Interpretation, supra note 9, at 205 . 
place within a context of the systemic application of statesanctioned force. ${ }^{34}$

Certainly the opinion of Johnson has had lasting and negative consequences on the legal rights of tribes and tribal citizens. But the story Justice Marshall chose to tell with his holding is also harmful-both as law and as cultural understanding. James Fenimore Cooper's novel popularizes Marshall's story by encoding it within a novel, a work of popular fiction that purports to present national history ${ }^{35}$ which was and is readily available to a wide audience.

Cooper's audience has dwindled, but the cultural work performed by his novels and by Marshall's opinion survives in the legal struggles of indigenous peoples and in public opinion or ignorance of those struggles. The lack of attention to the intersections of law and literature compound this problem and, ironically, may be attributed to the privileged status of each field. Until recently, law and literature were each associated with an elite cadre of white males and tended to reinforce the values of that group. ${ }^{36}$ Thus, looking at Bleak House for an understanding of Charles Dickens's view of the law of Chancery and the lawyers who work there ${ }^{37}$ or The Portrait of a Lady for Henry James's view of divorce ${ }^{38}$ is one aspect of the field. However, law and literature are well suited to the study of law from other perspectives. Literature has the ability to reflect many voices in ways the law cannot. As Edward Said has controversially argued, Jane Austen's Mansfield Park portrays the legacy of the slave trade in Fanny Price's ill-timed question to her uncle, an interpretation adopted and reinforced by Patricia Rozema's 1999 film

34. DoLIN, supra note 31 , at 10.

35. COOPER, supra note 3 , at 16 ("Only forty years have passed since this territory was a wilderness."). Cooper also includes a footnote in the 1832 edition saying that " $[\mathrm{t}] \mathrm{he}$ book was written in 1821-1822." Id. Clearly Cooper is anxious that the reader correctly date the events in the narrative and locate them within American history.

36. West, Literary Lawyer, supra note 7, at 1197. ("Outsider's voices have historically been censored from the language of literature and high culture at least as relentlessly as they have been banned from the language and courts of law. Supplementing one with the other might leave both bigger and richer, but supplementation alone will not leave either law or literature more inclusionary."). Of course, this article focuses on a piece of fiction that is certainly literature which is part of the canon. This goes, however, to the analysis of Cooper's fiction and its impact on his readers, the dominant white culture. Questioning the canon also has value as questioning the law-both seem inviolable, but both are incomplete.

37. RiCHARD H. WEISBERG, POETHICS, AND OTHER STRATEGIES OF LAW \& LITERATURE 68 (1992).

38. Melissa J. Ganz, 'A Strange Opposition': The Portrait of a Lady and the Divorce Debates, 27 HENRY JAMES REV. 156 (2006). 
version of the novel. ${ }^{39}$ Or more recently, scholars have considered the ways in which Louise Erdrich demonstrates the effects of allotment on Indian people in her novels. ${ }^{40}$

In other words, feminist scholars, critical race theorists, and others ${ }^{41}$ concerned about the impact of the dominant narrative of law on women and other minority groups when accepted unquestioningly as truth started using literary theory to study the writings of outgroup members and how they perceived the law or legal system. ${ }^{42}$ Law and literature studies thus become about "narrative legal scholarship"43 or the study of indigenous literary narratives. ${ }^{44}$

For example, Guyora Binder and Robert Weisberg identify ten common claims of "narrative legal scholarship," ${ }^{45}$ including that "stories most often repressed may be those reflecting the perspectives of subordinated groups" and that "inclusion of narratives, whether fictional or factual, in legal scholarship can morally improve the law . . . and advance the interests of subordinated groups." ${ }^{46}$ Bruce Duthu also argues for the importance of reading indigenous "literary narratives" next to cases of federal Indian law to create a more "polyphonic expression of human life." "47

Incorporating indigenous texts is vital to the study of federal Indian law, inserting the necessary counterbalance to the majority's law-making

39. Edward W. Said, Jane Austen and Empire, in RAYMOND WILLIAMS: CRITICAL PERSPECTIVES 150 (Terry Eagleton ed., 1989).

40. Kristen A. Carpenter, Contextualizing the Losses of Allotment Through Literature, 82 N.D. L. REV. 605 (2006).

41. DoLIN, supra note 31, at 8 ("Within literary studies, the significance of the legal context has been closely studied by feminist and postcolonial as well as new historicist critics. The value of such approaches for this study of fictional representations of law is that they produce a sharpened awareness of the dialectical relationship between novelistic and other signifying practices, or in the words of the new historicist Stephen Greenblatt, of 'the forms of power and the power of forms ...."”).

42. West, Literary Lawyer, supra note 7, at 1202 ("[T]he twentieth century 'law and literature scholars' engaged in the Critical Project are far more inclined to 'use' literature in such a way as to call into question the law's moral authority. The critical law and literature scholar uses literature as a means to open law to criticism, rather than to shield it from criticism within the protective shroud of high culture, and to push for greater democratization, rather than greater elitism, in legal processes.").

43. GUYORA BINDER \& ROBERT WEISBERG, LITERARY CRITICISMS OF LAW 201 (2000).

44. Duthu, supra note 11 , at 144.

45. BINDER \& WEISBERG, supra note 43, at 201.

46. Id.

47. Duthu, supra note 11 , at 144. 
narrative. ${ }^{48}$ In addition, however, it is necessary to point out and question the racist language used in the narratives of majority literature and law. ${ }^{49}$ In the case of Johnson $v$ M'Intosh, Justice Marshall's story becomes the stock story for future legal opinions as Cooper's representation of Templeton becomes conflated with the history of New York state. ${ }^{50}$ Countering these stories is a way to work toward Duthu's goal of "decolonizing federal Indian law [which] can only proceed if interpreters of legal texts develop a consciousness about these narrative constructs in order to generate effective strategies to limit, if not totally eliminate, their tendency to suppress the expression of tribalism.",51

The study of law and literature via narrative legal scholarship, then, concerns itself with the law in literature. It sometimes includes the law as literature and the inclusion of non-majority legal narratives into scholarship. A subset of law and literature not often addressed is that of legal fictions. In his book Legal Fictions, ${ }^{52}$ Lon Fuller defines and attempts to categorize legal fictions. He defines legal fictions as "(1) a statement propounded with a complete or partial consciousness of its falsity, or (2) a false statement recognized as having utility," 53 in other words, a statement that the judge knows is false and uses it as such.

Legal fictions are a type of storytelling where the fiction is created to make a smooth rule of law. By acknowledging the fiction, but accepting its basis, the fiction becomes rule of law and justifies the actions taken by the court. But

48. West, Literary Lawyer, supra note 7, at 1197.

49. Id. at 1199 ("To understand what laws need to be changed, overruled, cast out, or uprooted, we need to understand, foremost, their political impact, not their cultural heritage. We need to know who is hurt, and by how much, by the effect of law on the lives of its subjects. Such an inquiry is not analytically incompatible with a humanistic study of law's promise, and of its cultural heritage, but it is most assuredly different. There is a difference, and an important one, between a conception of law as a branch of humanities, and therefore something to preserve as well as improve upon, and a conception of law as a branch of politics, and therefore something to use, reform, change, or challenge toward the end of improving people's lives. . . . The invitation to read law as literature, and to read literature as a part of law, does sometimes enlighten, and can itself be an important engine for reform: it alerts us, minimally, to alternative ways of reading and using extant legal authority. Where the needed reform 'goes to the root,' however, it can also distract us from the task at hand.").

50. COOPER, supra note 3, at 9 . Thus, in his 1832 preface, Cooper feels compelled to differentiate between facts and fiction: "In order to prevent mistake, it may be well to say that the incidents of this tale are purely a fiction. The literal facts are chiefly connected with the natural and artificial objects, and the customs of the inhabitants." Id.

51. Duthu, supra note 11 , at 184-85.

52. FULLER, supra note 14.

53. Id. at 9 . 
this storytelling only works for those who are in the system-indeed, legal fictions are not necessarily written for a broad audience the way literature is, but for a narrow, legal audience. Since legal fictions are only understood by those within the legal community, they may become "truth" to the majority society and trickery to the minority group. Certainly their existence delegitimizes the law in the eyes of outsiders.

Thus, legal fictions represent a difficult concept to counter. They are created by a judge for convenience, to ensure the continued smooth application of the "rule of law." Those trained in law are supposed to be able to understand the falsity. Studying legal fictions is distinct from studying law as literature. A focus on legal fictions does not assume law is literature with its attendant concerns about the power of the law. ${ }^{54}$ Rather, questioning legal fictions allows scholars to question assumptions made by judges and others trained in the law and the impact of those assumptions on outgroups. The study of legal fictions also uncovers cases when a legal fiction is no longer considered a fiction, even by those in the know, and traces the impact of this slippage.

\section{Johnson v. M'Intosh: Legal Fictions, Historical "Facts" and Property Law}

Johnson v. M'Intosh ${ }^{55}$ is the first of the cases known as the Marshall Trilogy ${ }^{56}$ the basis of federal Indian law. Thus, Johnson is often the first case for students in federal Indian law class. However, recent arguments in Indian law claim that the "Marshall trilogy has fallen on hard times"57 and that it has become less and less relevant as the Supreme Court ignores the cases. ${ }^{58}$ Johnson, in particular, though, has reach outside of federal Indian law. The case is still taught in first-year property classes, often as the first case. ${ }^{59}$

54. But see Soifer, supra note *, at 882-83 ("Legal fictions are quite different from real, literary fictions. For one thing, as Bob Cover pointed out, potential violence lurks beneath the fictions created by judges, while the nexus between even the most powerful literary fiction and actual force is quite attenuated. Additionally, the author of real fiction enjoys more freedom than the creator of legal fiction.").

55. 21 U.S. (8 Wheat.) 543 (1823).

56. Matthew L.M. Fletcher, The Iron Cold of the Marshall Trilogy, 82 N.D. L. REV. 627 , 627 n.2 (2006) (citing CHARLES F. WILKINSON, AMERICAN INDIANS, TIME AND THE LAW: NATIVE SOCIETIES IN A MODERN CONSTITUTIONAL DEMOCRACY 24 (1987)). The other two cases in the trilogy are Cherokee Nation v. United States, 30 U.S. (5 Pet.) 1 (1831), and Worcester v. Georgia, 31 U.S. (6 Pet.) 515 (1832).

57. Fletcher, supra note 56 , at 647.

58. Id.

59. Jesse DUKEMINIER, JAMES E. KRIER, Gregory S. AleXANDER \& MichaEL H. SCHILL, 
Therefore, Johnson is unique in the trilogy, as it forms the initial, and perhaps only, exposure law students have to federal Indian law.

Johnson holds that Indian tribes have a "right of occupancy" and that tribes can only alienate that land to the United States and not any other sovereign (or individual). ${ }^{61}$ Chief Justice John Marshall created this chain of title by adopting the doctrine of discovery into federal common law. ${ }^{62}$ Justice Marshall used the doctrine of discovery in this decision to justify the role of the U.S. federal government vis-a-vis tribes. The discovery and conquest doctrine claims the first European sovereign to "discover" land holds the right to the title to the land and the right to conquer those who live there. However, Marshall also wrote pages of dicta justifying the decisions that make up the bulk of the opinion. This portion of the opinion is Marshall's "story," a narrative written solely to justify his finding; the story has little to do with the holding or with the facts of the case. Distinguishing between legal fictions, fictions, and bad facts requires a parsing of the opinion.

As has been well documented by Professor Lindsay Robertson, the history behind Johnson challenges the modern understanding of Supreme Court jurisprudence. ${ }^{63}$ The history of Johnson is a history of legal fictions. The case itself is a fabrication, constructed by one group of landowners. ${ }^{64}$ Professor Robertson's book charts this fiction and provides a character study of Robert Goodloe Harper, the former congressman and attorney ${ }^{65}$ who painstakingly attempted every avenue to have the purchases made by the Illinois and Wabash Land Companies from the Piankashaw and Illinois tribes recognized by the newly created federal government. ${ }^{66}$ When congressional action failed to accomplish his goal, Harper worked to have Indiana recognized as a state so

Property 3 (6th ed. 2006); JosePh Singer, Property LAW: RUles, Policies AND PraCtices 3 (4th ed. 2006); Jon W. Bruce \& James W. Ely JR., Modern Property LaW 2 (6th ed. 2007). Two other property books include the case within the first two chapters, THOMAS W. MERrill \& HENRY E. SMITH, Property: PrinciPles \& Policies 110 (2007), and SHELdONF. KURTZ \& HERBERT HOVENKAMP, AMERICAN PROPERTY LAW 70 (5th ed. 2007). Stuart Banner also points out the prominence of Johnson $v$. M'Intosh in DUKEMINIER ET AL., supra, in STUART BANNER, HOW THE INDIANS LOST THEIR LAND 11 (2005). However, while he argues the case in the book is criticized by professors as "anti-canon," only Singer's book actually does so.

60. Johnson, 21 U.S. (8 Wheat.) at 585.

61. Id.

62. Fletcher, supra note 56 , at 631.

63. LINDSAY G. ROBERTSON, CONQUEST BY LAW: HOW THE DisCOVERY OF AMERICA DISPOSSESSED INDIGENOUS PEOPLES OF THEIR LANDS (2005).

64. Id. at 47 (Illinois and Wabash Land Companies).

65. Id. at 3 .

66. Id. at 32-36. 
that a judicial claim could be heard by the Supreme Court. ${ }^{67}$ Harper "construct[ed] the suit," picking both the plaintiff and defendant to ensure diversity between parties and enough controversy to receive a hearing. ${ }^{68}$

Initially the case was brought under an easily identifiable legal fiction adapted from English courts. In a case to determine title to land, the plaintiff needed to initiate ejectment proceedings regardless of the actual existence of a trespasser. To do so, he used a fictitious tenant and fictitious trespasser. As Professor Robertson writes, the pleadings in district court were

formulaic, literally copied from form books . . . . Ejectment pleadings were formulaic because they were built on legal fictions: after the lands had been described, the plaintiff established jurisdiction by alleging that his tenant, who in fact did not exist, had been driven by force of arms ("vi et armis") from the disputed lands by the defendant's tenant, the "casual ejector," who also did not exist. ${ }^{69}$

To further illustrate this point, the casual ejector was named "Thomas Troublesome" and the tenant "Simeon Peaceable." The legal fiction of ejectment is easily recognizable and is the exact type used as an example by those writing about the place of legal fictions in the law seventy years after the case was decided. ${ }^{71}$

However, when scholars refer to the legal fiction of Johnson v. M'Intosh, they usually are not referring to the type of case brought. Indeed, sometimes it is unclear whether they are referring to the holding or the dicta or both. ${ }^{72}$

67. Id. at $45-47$.

68. Id. at 47.

69. ROBERTSON, supra note 63 , at 54 . This also demonstrates that legal fictions were certainly acknowledged as such in 1823, Marshall would have been familiar with them, and probably familiar with the debates between legal commentators such as Bentham and Blackstone as to their utility. See Peter J. Smith, New Legal Fictions, 95 Geo. L. J. 1435, 1466 (2007).

70. ROBERTSON, supra note 63 , at 57 . The statement of facts in the case was also a fiction, where Harper "eliminated all of the factual objections ever raised against the claim." Id. at 55.

71. Oliver R. Mitchell, The Fictions of the Law: Have They Proved Useful or Detrimental to Its Growth? 7 HARV. L. REV. 249, 250 (1893).

72. See e.g., William Bradford, Beyond Reparations: An American Indian Theory of Justice, 66 OHIO ST. L.J. 1, 9 n.39 (2005) ("the international legal fiction of 'discovery"'); Laura Nader \& Jay Ou, Idealization and Power: Legality and Tradition in Native American Law, 23 OKLA. CITY U. L. REv. 13, 19 (1998) ("Nowhere is the legal fiction and ambiguity more prevalent than in Supreme Court cases concerning Indian sovereignty. . . [ [I]n Johnson v. M'Intosh, Marshall held that the United States had preeminent sovereignty over its claimed 
This is an interesting question because the term "legal fiction" has clear requirements, not the least of which is that the judge using the fiction understands it as such. There is a serious question as to whether Marshall intended to write a legal fiction or took his holding at face value. It is difficult to determine whether he was "bamboozled"73 by the myth of the "vanishing Indian hunter" and used it to justify the more clearly mythical narrative of conquest or if he understood both the reasoning and the holding as a legal fiction.

First, we will consider the holding - that the doctrine of discovery necessarily limits tribal land rights and particularly tribal title to their own lands. Marshall wrote:

The United States, then, have unequivocally acceded to that great and broad rule by which its civilized inhabitants now hold this country. They hold, and assert in themselves, the title by which it was acquired. They maintain, as all others have maintained, that discovery gave an exclusive right to extinguish the Indian title of occupancy, either by purchase or by conquest; and gave also a right to such a degree of sovereignty, as the circumstances of the people would allow them to exercise. ${ }^{74}$

Marshall's opinion broadened the original legal argument to discuss tribal title to land..$^{75}$ In fact, the facts stipulated to in the case assumed the tribes owned the land and had authority to transfer it. $^{76}$ One explanation was that Marshall was trying to do too many things with his decision. Professor Robertson argues Marshall was looking forward to a second case in which he wanted to hold a certain way ${ }^{77}$ and thus expanded the decision beyond the legal question at hand. In fact, Professor Banner demonstrates the doctrine of discovery was

territory by virtue of the doctrine of 'Discovery' and the rights of 'Conquest."'); William D. Wallace, M'Intosh to Mabo: Sovereignty, Challenges to Sovereignty and Reassertion of Sovereign Interests, 5 CHI.-KENT J. INT'L \& COMP. L. article 5, at 4 (2005), http://www.kentlaw. edu/jicl/articles/spring2005/s2005_william_wallace.pdf(stating that Marshall's "extravagant" claims statement demonstrated Marshall's acknowledgment of the "legal fiction involved in his decision").

73. Fletcher, supra note 56 , at 675.

74. Johnson v. McIntosh, 21 U.S. (8 Wheat.) 543, 587 (1823).

75. ROBERTSON, supra note 63 , at 56 (stating that the purchases were made in violation of the Proclamation of 1763).

76. Id. at 54-55.

77. Id. at 83-89. 
not considered the "general rule of acquiring Indian lands," "78 but, by the time of the decision, Marshall's reasoning was not surprising for jurists. ${ }^{79}$ So the question becomes whether the holding of the case was intended as a legal fiction or as a "sincere" ${ }^{\text {" }}$ justification for clear title. ${ }^{81}$

Certainly, adopting the doctrine of discovery to justify land title fits some of the key requirements of a legal fiction. The discussion of legal fictions that use historic doctrines to justify new law is particularly apt to this case. As Fuller notes, "A judge may state new law in the guise of the old, not for the purpose of deceiving others, but because this form of statement satisfies his own longing for a feeling of conservatism and certainty." ${ }^{, 82}$ In addition, Fuller observes a solution to a case may involve a forcing of the case into existing categories instead of the creation of a new doctrine. ${ }^{83}$ While the doctrine of discovery was new to federal common law, the doctrine itself had its roots in the Crusades of the eleventh and twelfth centuries ${ }^{84}$ and was continued and revised by Spain and Portugal through the $1400 \mathrm{~s}^{85}$ The relatively new situation of determining title passed by tribes to individuals versus title passed by tribes to nations was not easily resolvable. The old doctrine of discovery was an existing category, whether it was the way a land tenure system had actually been operating at the time of the case or not.

The doctrine and its holding also has utility, eliminating questions about how land can be passed from tribes to sovereigns, limiting tribes ability to make alliances with other sovereigns on the continent who remained a threat to the United States, and limiting direct individual involvement with tribal land purchases. Indeed, Justice Story later wrote that the doctrine "was a 'most flexible and convenient principle." ${ }^{86}$ However, whether it was understood to be a "fiction" by other judges and lawyers at the time is questionable. ${ }^{87}$ Marshall himself wrote in the opinion that the doctrine of discovery was an

78. Fletcher, supra note 56, at 633.

79. BANNER, supra note 59 , at 183.

80. Id.

81. Indeed, legal fictions are often both intended as a fiction and as a justification, which is discussed infra.

82. FULLER, supra note 14 , at 58.

83. Id. at 68 .

84. Robert J. Miller, Native America, Discovered and ConQuered: Thomas JEFFERSON, LEWIS \& CLARK AND MANIFEST DESTINY 12 (2006).

85. Id. at 13 .

86. MilleR, supra note 84, at 11 (quoting The History and Influence of the Puritans, in THE MisCELlaNEOUS WRITINGS OF JOSEPH STORY 459 (William W. Story ed., 1852)).

87. BANNER, supra note 59 , at 179-88. 
"extravagant ... pretension" and that "[h]owever this restriction may be opposed to natural right, and to the usages of civilized nations, yet, if it be indispensable to that system under which the country has been settled ... it may, perhaps, be supported by reason, and certainly cannot be rejected by Courts of justice." demonstrate at least an ambiguous stance on the part of Marshall.

However, the fiction of the doctrine of discovery and conquest became fact troublesomely fast. ${ }^{89}$ By 1833 , Justice Story wrote that "title was founded on the right of discovery, a right, which was held among the European nations a just and sufficient foundation, on which to rest their respective claims to the American continent." As As Fuller writes, a legal fiction "taken seriously, i.e. 'believed,' becomes dangerous and loses its utility." the holding in Johnson continues in its danger, but also in its utility. The doctrine of discovery, perhaps a legal fiction at the time of its introduction into the federal common law, lost its fictional qualities quickly and became "history." As Professor Soifer writes, "We employ legal fictions to preserve a notion of continuity with the past, yet legal fictions help short-circuit attempts to comprehend the complexity behind the assumptions a legal fiction conveys. Like sunlight, legal fictions affect how growth will tilt." ${ }^{, 92}$

While the holding has had the most impact on tribal land rights, Marshall's extensive dicta played into the narrative of Indians, tribes, and removal on a broader cultural level. As Professor Banner notes, Marshall wrote his history and dicta portion of the case in eleven days, based primarily on flawed material. ${ }^{93}$ Marshall's discovery justification for his holding leads directly to Justice Reed's infamous statement about what "[e]very American schoolboy knows." Justice Reed cited to Johnson and the doctrine of discovery, which by 1955 had become a "legal theory," that "discovery and conquest gave the

88. Johnson v. McIntosh, 21 U.S. (8 Wheat.) 543, 591 (1823).

89. See, e.g., BANNER, supra note 59, at 164-65 (using congressional debate over the 1796 Trade and Intercourse Act to demonstrate a change in understanding of tribal title).

90. Fletcher, supra note 56, at 634 (quoting 1 JOSEPH STORY, COMMENTARIES ON THE CONSTITUTION OF THE UNITED STATES 2, 4 (1833)).

91. FULLER, supra note 14, at 9-10.

92. Soifer, supra note *, at 877 .

93. BANNER, supra note 59, at 183-84.

94. Tee-Hit-Ton Indians v. United States, 348 U.S. 272, 289 (1955) ("Every American schoolboy knows that the savage tribes of this continent were deprived of their ancestral ranges by force and that, even when the Indians ceded millions of acres by treaty in return for blankets, food and trinkets, it was not a sale but the conquerors' will that deprived them of their land."). 
conquerors sovereignty over and ownership of the lands thus obtained."95 The fiction of conquest continued its utility for the Supreme Court, even while all pretense of its fictional qualities in Marshall's writing was eliminated.

However, Marshall's dicta and reasoning, at the time, also fits Fuller's definitions of emotive or persuasive $\mathrm{e}^{96}$ and apologetic ${ }^{97}$ legal fictions. An "emotive fiction" is one that "seems to be intended rather to induce conviction that a given legal result is just and proper," "apologizes for the necessity in which the law finds itself of attributing to the acts of parties legal consequences that they could not even remotely have anticipated." In his initial history, Marshall focuses on grants from the various European crowns to the "discoverers" as evidence of a grant of the actual land. ${ }^{100}$ However, if this were the case, then the question remains why colonists still purchased land from the tribes and why the foreign governments entered into treaties. Professor Banner argues that "actual colonial land policy looked very different from the charters" and "contradicted" them. ${ }^{101}$ Banner goes on to argue, however, that Marshall believed the charters were not a "legal fiction."102 However, Marshall was a land speculator and knew the tribes initially sold land to individuals and colonial governments, contrary to the charters. ${ }^{103}$ Marshall's distinction between title and occupancy is a fiction created by him ${ }^{104}$ and successfully made transfers of land from a tribe to anyone other than a sovereign less than whole. Tribal right of occupancy is an emotive fiction, helping to "induce conviction" that the legal result here, title by discovery, is proper. ${ }^{105}$

In Marshall's other dicta he wrote an apologetic fiction: "Although we do not mean to engage in the defence of those principles which Europeans have applied to Indian title, they may, we think, find some excuse, if not

95. Id. at 279. Other authors have drawn connections between these two cases. See also Ball, supra note 12, at 2298-99; Nell Jessup Newton, At the Whim of the Sovereign: Aboriginal Title Reconsidered, 31 HASTINGS L.J. 1215, 1220-23 (1980); SINGER, supra note 59, at 19.

96. FULLER, supra note 14, at 54.

97. Id. at 84 .

98. Id. at 54 .

99. Id. at 84 .

100. BANNER, supra note 59 , at 183-84.

101. Id. at 79 .

102. Id.

103. Id. at 181 .

104. Id. at 29.

105. Id. at 181 ("To arrive at the conclusion that the Indians had merely a right of occupancy, Marshall pulled together several strands of early nineteenth-century legal thought, some old and some of relatively recent invention."). 
justification, in the character and habits of the people whose rights have been wrested from them."106 Marshall's contradiction here of not engaging in a defense but rather a justification also illustrates his problem with the initial holding. Judicially "conquering" tribes by taking title to their land requires more than just a single statement. It requires a palliative, an emotive fiction to smooth over the decision. Therefore, the tribal people must be "fierce savages, whose occupation was war, and whose subsistence was drawn chiefly from the forest. To leave them in possession of their country, was to leave the country a wilderness. ..."107 They were also no longer even on the land in question because, "[a]s the white population advanced, that of the Indians necessarily receded... The game fled into thicker and more unbroken forests, and the Indians followed. "The soil, to which the crown originally claimed title, being no longer occupied by its ancient inhabitants, was parcelled out according to the will of the sovereign power. ..."108 Even assuming these facts were true, and they are assuredly not, ${ }^{109}$ it is a fiction to "attribute [it] to the acts [of hunting of the parties] legal consequences that they could not even remotely have anticipated [loss of land and destruction of culture]."110

\section{Implications of Johnson's Fictions Today}

While the Marshall trilogy is less persuasive than it once was, Johnson has another life outside of Indian law-in first-year property classes, a requirement of most law schools. Marshall's use of legal fictions is usually glossed over; instead, the case is used to demonstrate the clear title for all land in the United States. It is important to note that even if the doctrine of discovery and Marshall's holding were recognized as legal fictions, they would still harm because they would retain utility. Indeed, the land title system in the United States is unlikely to be overturned in recognition that the Johnson holding was a legal fiction. But if it is recognized as such, it leaves room for other understandings of land takings. If Fuller's statement that "[a] fiction becomes wholly safe only when it is used with a complete consciousness of its falsity" 111 is true, then understanding Johnson as reality and not a falsity is the

106. Johnson v. M'Intosh, 21 U.S. (8 Wheat.) 543, 589 (1823).

107. Id. at 590-91.

108. Id.

109. See, e.g., BANNER, supra note 59, at 187 (noting that Marshall's account was a "wildly inaccurate account of colonial land acquisition"); Fletcher, supra note 56, at 675 (examples of tribal agriculture).

110. FULLER, supra note 14 , at 84.

111. Id. at 10 . 
danger. Seen as the historic truth, Johnson bars alternate histories. Seeing Johnson as a legal fiction used by a judge in 1823 renders it less powerful-a product of its time to be countered rather than the "true" history.

As Johnson depends on one's perception of the case, the manner in which popular textbooks treat the case is illuminating. Of five property case books surveyed, ${ }^{112}$ none of them refers to the holding of Johnson as a legal fiction, although one questions the reality of conquest in questions after the case. ${ }^{113}$ That book, Joseph Singer's Property Law, is unique in its discussion of tribes and land ownership. In addition to Johnson, Singer includes Tee-Hit-Ton Indians $v$. United States ${ }^{114}$ and directly connects current Indian land claims and City of Sherrill $v$. Oneida Indian Nation ${ }^{115}$ to the legacy of conquest. ${ }^{116}$

Other texts, however, do not include the same level of discussion. One uses Marshall's history and reasoning as an "explanation" for why the "common law system and its attendant concept of landownership c[a]me to supplant preexisting North American property regimes," with no further discussion of the troubling aspects of Johnson. ${ }^{117}$ Only one places Johnson within the Marshall Trilogy, ${ }^{118}$ and three have notes discussing the "outmoded" principles of "conquest and discovery."119 Dukeminier's Property gives students interested in learning more about "the legal situation of Native Americans" a footnote to Felix Cohen's Handbook of Federal Indian Law, making it the only casebook to reference the Handbook. ${ }^{120}$ However, Dukeminier's book also states "our concern here is not the complexities of title to land once occupied exclusively by Native Americans. We are interested instead in getting a study of property underway."121 Dukeminier relegates tribal title to land as too complex and no longer important while at the same time implying that the land is no longer occupied by tribes in one sentence.

112. BRUCE \& ELY, supra note 59; DUKEMINIER ET AL., supra note 59; KURTZ \& HOVENKAMP, supra note 59; MERRILL \& SMTTH, supra note 59; SINGER, supra note 59.

113. SINGER, supra note 59, at 13 ("Had the Piankeshaw and Illinois Indian Nations been conquered? When did that happen?").

114. 348 U.S. 272 (1955).

115. 544 U.S. 197 (2005).

116. SINGER, supra note 59 , at 22.

117. BRUCE \& ELY, supra note 59, at 2.

118. KURTZ \& HOVENKAMP, supra note 59 , at 79-80.

119. Id. at 85; see also DUKEMINIER ET AL., supra note 59, at 11-12; MERRILL \& SMITH, supra note 59, at 118-19. However, this book quotes Marshall's language about "fierce savages" who left the country "a wilderness" and claims these concepts have only "recently been called into question." Id.

120. DUKEMINIER ET AL., supra note 59, at $11 \mathrm{n} .1$.

121. Id. at 9 . 
With the exception of Singer's book, and indeed, his first chapter is a minihistory of tribes and tribal land claims, the property case books lack context. Students of Singer's book would at least be minimally aware of the false history of conquest. Rather than countering the understanding that tribes were "conquered" in the first place, the other books are more concerned about whether "conquest" is a valid way of assuming title. The books point out that "conquest" is no longer allowed by international treaties, and therefore, is "of little importance today." 122 Left standing, however, is the notion that conquest was what happened to tribes at the time, with little or no discussion of treaties and the fact that most land which was once tribal land was purchased by the government through those treaties. Indeed, these modern property books leave the impression that, although it was unfortunate, tribes were conquered by the United States, and therefore, white property owners were and are the title holders to the land. Is "conquest" then truly considered a "legal fiction"? Has the legal fiction of conquest become historical fact in the minds of lawyers whose first-year property law course provides their only exposure to Johnson v. M'Intosh? It seems likely that it has, but certainly Marshall's rather complicated opinion would not have the resonance it has today if it were not enforcing a larger majority cultural understanding of the "history" of tribes and land in the United States.

\section{The Pioneers: Memoir as Fiction}

The origins of this cultural narrative can also be located in a contemporary work of fiction. Published in the same year as Marshall's opinion, The Pioneers is James Fenimore Cooper's third novel and his second commercial success. ${ }^{123}$ The popularity of The Pioneers has been attributed to Cooper's depiction of the American landscape ${ }^{124}$ and the exclusively "American" characters who inhabit that landscape, particularly the frontiersman, Natty Bumppo, and the noble Indian, Chingachgook. Although Cooper draws on the tradition of historical romance popularized by Sir Walter Scott, his attention

122. Id. at 14; see also KURTZ \& HOVENKAMP, supra note 59, at 85 ("Acquisition of title by conquest generally is prohibited by a number of international treaties.").

123. CoOPER, supra note 3, at vii ("His first book, Precaution (1820), had been a weak imitation of British manners fiction; his second, The Spy (1821) a very successful romance of the American revolution. The Pioneers, his third, was Cooper's attempt to repeat his success with another novel based on American materials and depicting American life.").

124. See, e.g., Thomas Gladsky, The Beau Ideal and Cooper's The Pioneers, 20 STUD. IN THE NOVEL 43 (1988); COOPER, supra note 3, at vii. 
to American characters, landscape, and history provided a "usable past" for the fledgling American nation. ${ }^{125}$

In particular, Cooper attempts to resolve competing claims to the postRevolution American landscape through a complicated series of legal fictions intended to placate white landowners. It is worth noting that Cooper's novel appears only a few years before the Indian Removal Acts of the 1830s; ${ }^{126}$ Cooper's Chingachgook is typical of representations of Native Americans in the novels of this period. As others have noted, ${ }^{127}$ the "vanishing Indian" motif erases white guilt over Indian removal. However, less attention has been paid to the connections between Cooper's novel and the legal decisions that enabled Indian removal. Dolin explains: "[F]ictional narrative functions in the public sphere, contesting or supporting the dominant legal ideology. Central to [t]his methodology . . . is a dialectical understanding that novels can represent legal and alternative world-views and that the law itself can structure those literary representations." 128 Thus the ongoing debates over Indian removal inform Cooper's novel, which in turn informs the popular perception of Indians and their legal and political fate.

The plot of The Pioneers can be summarized as follows: a mysterious young hunter introduced as Oliver Edwards arrives in the community of Templeton, located in upstate New York. He lodges with a frontiersman, Natty Bumppo, and the "last Mohican," Chingachgook. Out hunting one day, he is accidentally shot by the town founder and leader, Judge Marmaduke Temple, who has just returned to town with his daughter, Bess. Oliver reluctantly agrees to reside with the Temples and work as Judge Temple's assistant, although he is inexplicably resentful of the Judge. Romance blossoms between himself and Bess Temple, although their social position appears profoundly unequal. Various catastrophes occur, but at the end of the novel the reader discovers that Oliver is the grandson of the original owner of the land on which Templeton sits, the British aristocrat and army officer Major Effingham, whose son befriended Marmaduke Temple. Moreover, we discover that although the Effinghams received the patent from the British Crown, Chingachgook also granted Major Effingham the same tract of land in

125. VAN WYCK BROOKS, AMERICA'S COMING OF AGE (1915) (first instance of the concept of a "usable past").

126. David H. Getches, Charles F. Wilkinson \& Robert A. Williams JR., Federal INDIAN LAW 125-26 (5th ed. 2005).

127. See, e.g., BRIAN W. DIPPIE, THE VANISHING AMERICAN: WHITE ATTITUdES AND U.S. INDIAN POLICY (1982).

128. DoLIN, supra note 31 , at 3. 
return for saving his life. The Effinghams remained loyal to the crown during the American Revolution and thus lost their title at the end of the war. Marmaduke Temple purchased the land at auction and started the settlement, but he claims that he has secretly held it in trust for the Effinghams. Natty Bumppo is discovered to be the loyal servant of Major Effingham, and we learn that he tended Major Effingham in his illness and attempted to protect his land. At the conclusion of the novel, Major Effingham and Chingachgook die, Natty heads west, and Oliver and Bess marry, thus uniting the two remaining claims to the land. The book has a similar land title structure to that in question in Johnson: one chain from the crown and one directly from the tribe. Only by combining the two, title to land and title to occupance, is full title achieved.

Although this plot summary emphasizes the fictionality of Cooper's text, Cooper's readers understood the novel as memoir. In the 1832 preface to the novel, Cooper draws connections between his father's settlement of Cooperstown and Judge Temple's of Templeton. Cooper later claimed The Pioneers was not based on the reality of Cooperstown and Judge Cooper, but he initially promoted this understanding of his book and, from comments in the 1832 and 1851 prefaces, it seems clear that Cooper's reading audience made such connections. More recently, many literary critics have accepted The Pioneers as closer to biography than to fiction. ${ }^{129}$ While not at the level of a Supreme Court decision, if the contemporary readers of The Pioneers understood the novel as what we would now call a memoir, the stereotypical characters and vanishing Indian plot become more "true" to the reading audience. Thus, Cooper's novel straddles the worlds of fiction and memoir with the expectation that readers of the text would understand the novel in this same double sense and that doing so would gratify their expectations.

The "double meaning" provided by Cooper's combination of fiction and memoir is particularly evident in his portrayal of Judge Temple. Not only does a discussion of Judge Temple provide a place to discuss land in The Pioneers, a topic vital to the book and the Johnson opinion, he was also modeled on Cooper's father, William, founder of Cooperstown, a land speculator, judge, and congressman. William Cooper's Town ${ }^{130}$ provides a detailed account of William Cooper's life and draws parallels to The Pioneers. The connections between William Cooper and Judge Temple illustrate how Cooper's novel

129. See, e.g., Michael Clark, Biblical Allusion and William Cooper in James Fenimore Cooper's The Pioneers, U. DAYTON REV., Summer 1987, at 105.

130. TAYLOR, supra note 6. 
attempts to replicate and naturalize the legal fictions by which his father, William Cooper, acquired his property.

William Cooper was a land speculator in New York, where "no other New Yorker had his hands in more frontier land speculations."131 Cooper received his land either directly from tribes ${ }^{132}$ or through shady dealings. Those dealings, particularly the one involving land originally owned by the speculator Col. George Croghan, made up the bulk of what would become Cooperstown. ${ }^{133}$ Croghan owned most of the land throughout Otsego County, which he obtained directly from the Iroquois in $1768 .{ }^{134}$ At that tribal council meeting, Croghan paid less than one shilling per acre for 245,000 acres of land that was, by treaty, reserved for the Crown. ${ }^{135}$ After his death, the land went up for auction twenty years later. At the "highly irregular auction"136 William Cooper won the patent to the land in Otsego County. The title to the land that became Cooperstown was thus twice clouded. Cooper's actions in the auction and throughout his time as a speculator made him a controversial figure. ${ }^{137}$ As Alan Taylor writes:

During the late 1790s Cooper was challenged simultaneously from within his own party by genteel men who disdained his rough edges and from without by rural democrats who saw him as a would-be aristocrat. Only partially successful at genteel reinvention, he was vulnerable to calumny and ridicule from both the common and polite. By trying and failing to become a polished gentleman, Cooper only hastened the collapse of his public authority. ${ }^{138}$

William Cooper served in Congress from 1795-96 and 1799-1800. During his 1795-96 session, he voted on the Intercourse Act. ${ }^{139}$ Interestingly, in the debate over this act, various congressmen put forth their understanding of tribal title to land. Cooper stood up to say that "the idea advanced by the gentleman from North Carolina, that Indian nations could not hold the fee of

131. Id. at 113 .

132. Id. at 4.

133. Id. at 46-47.

134. Id. at 46 .

135. Id. at $46-47$.

136. Id. at 70 .

137. Id. at 4,70 .

138. Id. at 6.

139. BANNER, supra note 59 , at 165. 
the countries they possess, was new" and "contrary to natural justice." 140 Given the nature of his own title, most of it directly from tribes or private speculators, if tribes did not have title to the land, his speculations were also in danger. Indeed, Cooper may have been aware of the similar land situation in Illinois that was the basis of the Johnson case because, for years prior to the decision, the land speculators involved tried to get congressional approval for the land purchases $^{141}$

Like William Cooper, Judge Temple is obsessed with his own role as a gentleman. He is also particularly concerned with the enforcement of the rule of law, but only when it is convenient for him. In other words, Judge Temple also uses legal fictions to achieve his end results. Judge Temple's largest legal fiction, of course, concerns land rights. At the conclusion of the novel, Judge Temple reveals that he has held the Effingham property in trust for Oliver: "One half of my estates shall be thine as soon as they can be conveyed to thee; and if what my suspicions tell me, be true, I suppose the other must follow speedily." 142 Although Oliver appears perfectly satisfied with this conclusion, it is strange that Judge Temple only restores half of the Effingham property, while reserving the other half for his daughter, Bess. While the Judge has a clear chain of title to the property, purchased at an auction after the American Revolution, he also feels a moral obligation to the previous owners, the Effinghams, who received the property as a land grant from the Crown and also as a grant from Chingachgook, who, as chief of the Mohicans, was entitled to make such a grant. "The land was owned by my people: we gave it to my brother, in council - to the Fire-Eater."143 Natty's reply to Chingachgook's explanation is telling, "[I]t was a comfortable hunting-ground then, lad, and would have been so to this day, but for the money of Marmaduke Temple, and the twisty ways of the law."144

In other ways as well, James Fenimore Cooper uses the character of Judge Temple to illustrate the "twisty ways," or fictions, in the rule of law. Cooper seems to write a book that is at least ambiguous in its stance on the dignity of rule of law. Given his own father's vulnerability to ridicule as a judge and a congressman, it is unsurprising Judge Temple is subject to the same. Like William Cooper, Judge Temple exploits his position as judge on numerous occasions in the novel. In the first deer hunt, the judge stages a mock trial to

140. Id. at 167.

141. ROBERTSON, supra note 63 , at 18-23.

142. COOPER, supra note 3 , at 443-44.

143. Id. at 291 .

144. Id. 
determine which hunter has the right to the deer. After being "out-voted -over-ruled as we say on the bench"145 by Natty and Oliver, he switches tactics and offers to pay them for the venison. When Oliver reveals that Judge Temple's shot has missed the deer and instead wounded him, Judge Temple's reply is telling: "I here give thee a right to shoot deer, or bears, or anything thou pleasest in my woods forever. Leatherstocking is the only other man that I have granted the same privilege to; and the time is coming when it will be of value. But I buy your deer - here, this bill will pay thee, both for thy shot and my own." 46 Judge Temple uses his authority as judge and prominent landowner to essentially bribe Oliver into silence.

Later in the novel, when Judge Temple is absent, a group of lawyers debate Oliver's case: "I ask you gentleman, supposing this to be the case, whether a jury wouldn't give what I call handsome damages?"147 In the discussion that follows, the lawyers claim that no man is above the law, but they are eventually silenced by Betty Hollister, who notes that Judge Temple "has a purse as long as one of them pines on the hill, and who is an asy man to dale wid, if yees but mind the humour of him."148 Betty's observation makes it clear that Judge Temple is not the impartial enforcer of the law he wishes to appear, but rather a wealthy man able to exert his will without suffering the consequences. Indeed, Judge Temple places his own cousin, Richard Jones, in the position of sheriff, which allows him to exert control over both the apprehension and trial of suspected criminals.

Cooper also illustrates a mixed view of the Western rule of law. As Elizabeth says to Chingachgook, "[I]f you knew our laws and customs better, you would judge differently of our acts," 149 a twofold plea. Certainly the Indians of that place would ask for the same understanding, rather than be dismissed as "fierce savages, whose occupation was war."150 Cooper's

145. Id. at 24.

146. Id.

147. Id. at 152 .

148. Id. at 153.

149. COOPER, supra note 3, at 402 . Elizabeth's plea also echos Thomas Jefferson's writing. See Ball, supra note 12, at 2306 ("In a typically liberal-hearted gesture, Thomas Jefferson enjoined Indians to enclose lands and take up farming. Once their land became property, he added, they would then want laws for its protection. Jefferson concluded: 'You will find that our laws are good for this purpose; you will wish to live under them, you will unite yourselves with us, join in our great councils and form one people with us, and we shall all be Americans; you will mix with us by marriage, your blood will run in our veins, and will spread with us over this great island."')

150. Johnson v. M'Intosh, 21 U.S. (8 Wheat.) 543,590 (1823). 
depiction of the rule of law acknowledges, to a limited degree, the legal fictions necessary to impose the Western rule of law. Indeed, Cooper's law is twisted, as the judge values the "law" over his daughter and condemns Bumppo to jail and to pay a fine he cannot pay. The judge, however, gives money to his daughter to pay Bumppo's fine, creating an obsession with technicality and with the fiction of an impartial judge. As Judge Temple tells Bess, "Nothing short of the twelve dollars and a half will satisfy this harpy [the magistrate], I perceive; and surely my reputation as a Judge is worth that trifle" 151 Although Judge Temple is anxious to be perceived as a fair judge, he seeks out legal loopholes to satisfy both his sense of natural law and his desire to uphold the Western rule of law. As Bess tells Oliver, "[M]y father is a Judge, but he is a man, and a Christian. It is all understood, and no harm shall follow." 152 And, indeed, in Natty's trial, no real harm does follow. Judge Temple skillfully manipulates the jury to ensure that it finds as he wishes. ${ }^{153}$ Judge Temple's rule of law is as full of twisty dealings as Marshall's opinion.

\section{Legal Fictions: Johnson v. M'Intosh and The Pioneers}

In his oft-anthologized poem "How to Write the Great American Indian Novel," Sherman Alexie satirizes white stereotypes of Native cultures. ${ }^{154}$ Although Alexie is directly borrowing from romance novels, the genealogy of this stereotype can be traced to Cooper's strong and silent Indians. The difference is, of course, that Alexie and others can deconstruct such stereotypes or ignore them by writing compelling Native characters into the literary canon. Literature forever reinvents itself. The law, however, relies heavily on the notion of precedent. Justice Marshall's legal fictions are therefore much more difficult to rewrite or reject. While The Pioneers and Johnson may have either reinforced existing beliefs or been recognized as legal fictions at the time of publication, their influence today continues to reinforce outmoded thoughts-and whether discovery and conquest is a legal fiction in the minds of most lawyers, nevermind most non-Indian U.S. citizens, is certainly up for debate.

In his decision, Marshall notes that the conqueror's limits are prescribed by "public opinion." These limits are that the "conquered shall not be wantonly oppressed, and that their condition shall remain as eligible as is compatible

151. COOPER, supra note 3 , at 330.

152. Id. at 343.

153. Id. at $364,369-72$.

154. Sherman ALEXIE, How to Write the Great American Indian Novel, in THE SUMMER OF BLACK WIDOWS 94-95 (1996). 
with the objects of the conquest." Given the release of The Pioneers in 1823, its popularity, and Cooper's stated intent to write a "descriptive tale" about the early American landscape, certainly Cooper's characters and stereotypes help to create this public opinion. Or, as Cheyfitz claims, "The Pioneers asked and asks its readers to take this authority [Judge Temple] seriously, just as seriously as the Johnson case asks its readers to take its authority."155

In contrast, Thomas Hallock argues that Cooper wrote The Pioneers as a way to create a new myth about the West, to "explain away a legacy of conquest."156 Hallock claims that whatever Cooper's "faults" were as an author, he "realized that nations were narrated, that those narratives were inherently unstable because challenges to authority were endemic to border society . .."157 Two things of note, the first is that The Pioneers does not explain away a legacy of conquest. Rather, it reinforces Marshall's use of the legal fiction of discovery and conquest by presenting it as (albeit fictionalized) American history. Indeed, Hallock's statement indicates his own belief in the history of conquest, anathema though he may find it. Second, nation-defining narratives are only open to challenge by those in power. It is highly unlikely that an alternative to conquest, say, the history of treaty-making from a tribal perspective, would have been considered a significant challenge to Cooper's history, even as he was crafting it.

Instead, popular white writers, including James Fenimore Cooper, Catharine Maria Sedgwick, Lydia Maria Child, and others, ${ }^{158}$ were crafting a more insidious and familiar myth: the Vanishing American. In novels published in the early nineteenth century, these authors repeatedly presented indigenous characters that willingly leave, die, or disappear from the American landscape. In Sedgwick's Hope Leslie, ${ }^{159}$ the narrator describes the departure of the Pequod from the colonies as follows:

Before the dawn of the next morning, this little remnant of the Pequod race, a name at which, but a few years before, all within the bounds of the New-England colonies -- all, English and Indians, 'grew pale,' began their pilgrimage to the far western forests. That

155. Cheyfitz, supra note 16 , at 119.

156. HALLOCK, supra note 29, at 202.

157. Id. at 202.

158. See, e.g., Lora Romero, Vanishing Americans: Gender, Empire, and New Historicism, 63 AM. LITERATURE 385 (1991) (counting over forty novels published between 1824 and 1834 that feature this trope.).

159. Catharine Maria Sedgwick, Hope Leslie (Carolyn Karcher ed., Penguin 1998) (1827). 
which remains untold of their story, is lost in the deep, voiceless obscurity of those unknown regions. ${ }^{160}$

Similar passages occur in Child's Hobomok, ${ }^{161}$ in which the Indian hero of the title voluntarily divorces his wife and becomes a wanderer so that she may marry an earlier, white lover. This pattern is continued in much of Cooper's work, but especially in The Last of the Mohicans and The Pioneers.

The Last of the Mohicans ${ }^{162}$ was published in 1826 as a sort of prequel to The Pioneers; it also is a clear source of inspiration for Sedgwick's Hope Leslie, published a year later. In the novel, readers are introduced to Chingachgook's son, Uncas, who falls in love with one of the heroines, Cora, and dies trying to defend her. As Lora Romero has argued, the novel is full of "precipitous aboriginal[s]"163 and Uncas's death is presented as the culmination of a series of Indian deaths. Read in the context of The Pioneers, however, Uncas's death becomes even more disturbing. Cooper never mentions Chingachgook's immediate family in The Pioneers and Chingachgook describes himself as the last of his tribe; thus, readers of The Last of the Mohicans, published three years after The Pioneers, would already know that Chingachgook's son, like Chingachgook himself, is doomed to die.

In The Pioneers, Cooper depicts the Vanishing Indian as already the last of the Mohicans, already the relic of a previous age. Unable and unwilling to completely assimilate to white culture, Chingachgook is rendered impotent by age. Cooper initially suggests that Chingachgook's contact with white culture is responsible for his weakness: "Is John old? When was a Mohican a squaw, with seventy winters! No! The white man brings old age with him - rum is his tomahawk!"164 This moment is powerful in its willingness to assign responsibility to white culture; however, Cooper's later descriptions of Chingachgook's weakness efface white agency: "But John is old; his hand is the hand of a squaw; his tomahawk is a hatchet; brooms and baskets are his enemies - he strikes no other." 165 In this passage, Cooper describes Chingachgook as fully domesticated; his tomahawk exchanged for the domestic implements of hatchet, broom, and basket. Chingachgook will only

160. Id. at 359.

161. Lydia MARIA ChILD, HobOMOK AND OTHER Writings ON INDIANS (Carolyn L. Karcher ed., Rutgers University Press 1995) (1824).

162. JAMES FENIMORE COOPER, THE LAST OF THE MOHICANS (Richard Slotkin ed., Penguin 1986) (1826).

163. Romero, supra note 158 , at 392.

164. COOPER, supra note 3 , at 185.

165. Id. at 207. 
reject his domesticated position at the end of the novel when he commits suicide: "John's hand can make baskets no more - he wants no shirt." he prepares for death, Chingachgook appears in full regalia and rejects the marks of assimilation offered by Bess: he will not trade with her; he will not accept the shirt she offers, and thus assimilate to the dress of the settlers, but instead appears bare-chested. Bess's response, "I feel as if you had a natural right to order what you will from us," 167 is typical of her heightened awareness of Chingachgook's plight at the end of the novel; significantly, Bess only realizes the complexities of her father's title to Templeton when the other claimants are near death. Thus Cooper, to borrow Duthu's phrasing, "bloodlessly conquers"168 tribes through his stand-in, Chingachook, who nobly kills himself, relieving the whites (and particularly Elizabeth) from having to scrutinize the basis of their land holdings.

Chingachgook's mysterious pronouncements about Oliver's land rights are explained by Oliver at the conclusion of the novel, thus resolving the last obstacle to clear title: "[Natty] was left here as a kind of locum tenens on the lands that old Mohegan (whose life my grandfather once saved) induced the Delawares to grant to him, when they admitted him as an honorary member of their tribe."169 Oliver's declaration redefines Natty's identity as well as his own: Natty is not an aging but independent hunter, instead he is the faithful servant of a British aristocrat; Oliver is not Chingachgook's blood relative, but an adopted member of his tribe. These revelations disenfranchise Natty while paving the way for Oliver's enfranchisement: without any "Indian blood," and with a conveniently aristocratic pedigree, Oliver Edwards Effingham may inherit his father's property and marry Bess, the heiress of the remainder of Templeton according to Western law.

Within Cooper's novel, Marshall's concern with the "actual state of things" ${ }^{\prime 70}$ is echoed in Bess's discussion of the land she inherits. In a conversation with Edwards, Bess states she "grieve[s] when [she] see[s] old Mohegan walking about these lands ... and feel[s] how small" her own "right" is to possess the lands. ${ }^{171}$ What is to be done, however? If she and her father "offer[ed] the old man a home and maintenance, his habits would compel him to refuse us," and certainly she would never be so foolish as to

166. Id. at 400 .

167. Id.

168. Duthu, supra note 11 , at 184.

169. COOPER, supra note 3, at 441.

170. Johnson v. M'Intosh, 21 U.S. (8 Wheat.) 543, 591 (1823).

171. COOPER, supra note 3 , at 280. 
"convert these clearings and farms, again, into hunting grounds," assuming, of course, what the old man wants is "hunting grounds" in the first place.

For Cooper, as for Marshall, the settlement cannot be returned to native tribes because it has already been settled. In fact, in the passage above, Bess describes Chingachgook as "the ghost of one of [the land's] ancient possessors." ${ }^{172}$ For Cooper's characters and Marshall, settlement is necessarily an improvement that cannot and should not be undone. Both contribute to the legacy of the fiction of impossibility, a fiction harming tribes and tribal people to this day. ${ }^{173}$ Believing it "impossible" to return the land to the Indians for various reasons (racism, settlement, manifest destiny), both needed a justification for keeping the land. Indeed the legal basis for the title to the land Cooper was writing about is based entirely on the vanishing Indian, and Cooper's representation of the vanishing Indian both satisfies any lingering anxiety over the white settlers' title to the land and works to prevent anxiety over the upcoming Indian Removal Acts.

Cooper illustrates the impossibility of returning the land to "hunting grounds" by imposing the rule of law over the hunting of deer. Indeed, the introductory scene and the main conflict in the book center around the date on which a deer is killed. Imposing the rule of law over hunting is the same thing as imposing the rule of law on the Native himself. In yet another example of the vanishing Indian, banning hunting, so closely tied to the lone Indian representative in the book, is essentially banning the Indian from the land.

Although The Pioneers predates the Indian Removal Acts of the 1830s, it performed a kind of cultural work by enabling readers to believe that the

172. Id.

173. City of Sherrill v. Oneida Indian Nation, 544 U.S. 197, 219-20 (2005). In this tax case the Supreme Court held that the doctrines of laches, acquiescence and impossibility prevented the Oneida Indian Nation from exercising sovereignty over its own lands. In particular, the impossibility doctrine is based on the fact that the land around the Oneida Nation's land is now owned by non-Indians, thus making it "impossible" for the tribe to exercise sovereignty. The Court's citations and quotes regarding impossibility sound remarkably like those expressed by Elizabeth and Justice Marshall: "Finally, this Court has recognized the impracticability of returning to Indian control land that generations earlier passed into numerous private hands." Id.; see Yankton Sioux Tribe v. United States, 272 U.S. 351, 357 (1926) ("It is impossible . . . to rescind the cession and restore the Indians to their former rights because the lands have been opened to settlement and large portions of them are now in the possession of innumerable innocent purchasers ...."); Felix v. Patrick, 145 U.S. 317, 334 (1892) (observing, in declining to award equitable relief, "[t]hat which was wild land thirty years ago is now intersected by streets, subdivided into blocks and lots, and largely occupied by persons who have bought upon the strength of Patrick's title, and have erected buildings of a permanent character").; see Kathryn E. Fort, The (In)Equities of Federal Indian Law, FED. LAW, Mar./Apr. 2007, at 32. 
Indian removal had already happened. ${ }^{174}$ This kind of cultural work is particularly dangerous, as it creates a sort of self-fulfilling prophecy. Readers who believed that Indian removal had already occurred based on the repeated representation of vanishing Indians in popular fiction did not object to the legal procedures that enacted the "real" removal. As Thomas Hallock observes, "Critics of romantic literature note that elegies for the vanished race were a shorthand for dispossession."175 Thus it is unsurprising to find Marshall borrowing from and contributing to this series of representations in his opinion and to find similar representations in Andrew Jackson's speeches in support of Indian removal. ${ }^{176}$

The confluence of The Pioneers and Johnson certainly demonstrates how law and literature equally influence the public, and especially the educated, white, male public. These fictions, then, become the legal loophole, particularly in Johnson, that allows the Court to remove title from the indigenous peoples. While Marshall was writing as a nineteenth-century white man, and thus had certain understandings of people who were not white or male, he nonetheless broadened his holding in Johnson to include any number of legal fictions to bolster his point. As Professor Robertson writes,

For the present, Marshall had no interest in considering alternatives to his history. His aim was to present evidence in support of his principal conclusions, which were that 'all the nations of Europe, who have acquired territory on this continent, have asserted in themselves, and have recognized in others, the exclusive right of the discoverer to appropriate lands occupied by Indians,' and that the sovereigns of Europe had granted lands still in possession of Indians. ${ }^{177}$

174. Cf. Scheckel, supra note 16 , at 145 ("Describing the dispossession of the Indians in terms of generational change erased both violence and responsibility from the process."). Scheckel focuses on mourning the generational passing to make removal easier for whites.

175. HALLOCK, supra note 29, at 198.

176. Andrew Jackson, First Annual Message, in A COMPILATION OF THE MESSAGES AND PAPERS OF THE PRESIDENTS 1021 (James D. Richardson ed., 1897), available at http://gutenberg.org/dirs/1/0/8/5/10858/10858.txt ("Our ancestors found them the uncontrolled possessors of these vast regions. By persuasion and force they have been made to retire from river to river and from mountain to mountain, until some of the tribes have become extinct and others have left but remnants to preserve for awhile their once terrible names."); Andrew Jackson, Second Annual Message, in A COMPILATION OF THE MESSAGES AND PAPERS OF THE PRESIDENTS, supra, at 1063-92, available at http://gutenberg.org/dirs/1/0/8/5/10858/10858.txt.

177. ROBERTSON, supra note 63 , at 103. 
Thus, the problem with Marshall's writing goes beyond what we see today as racist ramblings about the role of Indians and their land. The issue with Marshall's legal fictions was that there were other histories to consider and that he knew what they were. They included the fact that many land transactions were just that-transactions of title, not by conquest or discovery, but by contract. We see Marshall's discomfort with this fiction in the opinion itself: "Conquest gives a title which the courts of the conqueror cannot deny, whatever the private and speculative opinions of individuals may be, respecting the original justice of the claim which has been successfully asserted."178 Despite his "private and speculative opinions," however, the holding stands; the rule of law prevails.

Cooper presages Jackson's famous, apocryphal line regarding a later Marshall decision when Natty says that Judge Temple "may sintence, but he can't keep"179 Natty in his prison. President Jackson, of course, supposedly stated that "Marshall has made his decision; now let him enforce it," regarding Worchester v. Georgia. ${ }^{180}$ These descriptions belie the "rule of law," precious as precedent to lawyers and judges, making "law" convenient for majority culture. Not only is the law based on racist understandings of indigenous peoples, but it also is applied selectively. In this way, it is important to note that Cooper only critiques the rule of law as it applies to Natty Bumppo, a character sympathetic to indigenous rights but entirely white. Natty, not Chingachgook, is the victim of Temple's hunting regulations, and Natty is tried and condemned for this violation of the law. Thus, while Cooper is willing to acknowledge that Western rule of law is far from perfect, he is not willing to examine the direct impact of rule of law on indigenous peoples. Indeed, instead of directly confronting white usurpation of Native lands, Cooper creates an extensive legal fiction to justify Temple's claim to the land and insists that Chingachgook support such a claim.

Two other scholars have analyzed The Pioneers and Johnson v. M'Intosh, one from a literature perspective ${ }^{181}$ and one from an Indian studies perspective. $^{182}$ Both serve as a foundation for our argument. However, most analysis of Cooper is not under the rubric of law and literature, and of those readings that did consider the role of law in Cooper's fiction, the standard

178. Johnson v. M'Intosh, 21 U.S. (8 Wheat.) 543, 588 (1823).

179. COOPER, supra note 3 , at 389.

180. GETCHES ET AL., supra note 126, at 122 (includes a discussion of the sources of the likely apocryphal statement).

181. Scheckel, supra note 16.

182. Cheyfitz, supra note 16. 
reading of The Pioneers has focused on the struggle between Natty Bumppo's "natural law" and the victory of rule of law. ${ }^{183}$ Although this critique, like Cooper's novel, acknowledges the appeal of Natty's "natural law," it also confirms the necessary imposition of the rule of law on the wilderness. Thus, this type of literary critique, in its mere existence, continues to reinforce Cooper's stereotypes, leaving the "frontier" as an empty, lawless place. ${ }^{184}$ Moreover, the frontier is ever receding. At the conclusion of the novel, as Natty heads west, Cooper and his readers are well aware that he is "foremost in that band of Pioneers, who are opening the way for the march of the nation across the continent"185 and thus destroying his own way of life.

\section{Conclusion}

The "twisty ways of the law" are prevalent both in Cooper's novel and in Marshall's opinion; in both texts, these "twisty ways" take the form of legal fictions. Marshall's fiction continues to haunt Indian law today, much like Cooper's fiction continues to provide stock characters for literature. Marshall's "right of occupancy," "title by conquest," and "actual state of things" can be as difficult to accept (or should not be accepted) in Indian law as Cooper's "happy hunting grounds," the vanishing Indian, and actual state of things. Marshall's fictions, however, have been more difficult to counter in U.S. laws and courts than Cooper's have been in literature. This, of course, is because Marshall's fictions are cloaked in the authority of law, while Cooper's can be dismissed as fiction.

Yet, as we have argued, The Pioneers was not solely understood as fiction: Cooper's readers read it as both fiction and memoir, and thus its representation of Judge Temple as a noble but flawed arbiter is also a representation of Cooper's father. Cooper grapples with his own past, but his novel represents that past as necessary to the national future: this fictionalized past lays the groundwork for the Western rule of law. Judge Temple is succeeded by Bess and Oliver, who more successfully negotiate the compromises between civil and natural law, free of the difficult presence of indigenous peoples.

Yet, although the novel concludes with the wedding of Bess and Oliver, it also concludes with two funerals: the burial of Chingachgook and Major Effingham. Elizabeth and Oliver read the tombstones to Natty, who

183. See Kelly Stern, Cooper's The Pioneers, 55 EXPLICATOR 208, 208-12 (1997); Scheckel, supra note 16.

184. See Brook Thomas, The Pioneers, or Sources of American Legal History: A Critical Tale 36 AM. Q. 86 (1984); Cheyfitz, supra note 16, at 119.

185. COOPER, supra note 3 , at 456. 
catches—of all things—a spelling error: Chingachgook's name is misspelled. Oliver promises to correct the inscription, but this scene underscores the failure of white culture to "write" the Indian. In contrast with Chingachgook's death-marked by a thunderbolt, no less-Elizabeth and Oliver's misspelled tombstone, with its backhanded platitudes about Chingachgook's worth, reveals the failure of white narrative and the danger of inscribing such narratives in stone or in law. 
HeinOnline -- 33 Am. Indian L. Rev. 110 2008-2009 